\title{
Cooperative Script Learning Model to Improving Student Listening Skills
}

\author{
Muliadi \\ Teacher At Smp Negeri 1 Soropia, Southeast Sulawesi, Indonesia
}

\begin{abstract}
The purpose of this study is to improve the ability of listening students of class VII SMPN 1 Soropia, can be improved through cooperative script learning model.

The type of study was classroom action research, conducted in two cycles. Each cycle consists of planning, execution of action, observation, evaluation, and reflection. The subjects of the study were students in grade VII Semester 1 of SMPN 1 Soropia are 24 students. Sources of data in this study are students and teachers. The type of data in this study is quantitative data obtained from the test results and qualitative data obtained through the observation sheet.

The results showed the percentage of students' learning mastery obtained in the first cycle obtained an average value of 61.09 with a percentage of classical completeness $45.83 \%$ and increased in cycle II with average start to 81.00 and the percentage of mastery classically $87,50 \%$. The improvement of listening ability with the use of cooperative script learning model is supported by teacher and student observation result. Observation result showed teacher teaching activity reached $75,65 \%$ in cycle I increased to $86,84 \%$ in cycle II. Student learning activity in cycle I that is 69,64\% increase in cycle II become $86,54 \%$.

Based on the results of research and discussion, it is concluded that the results of student learning on the subject of the elements of children's stories can be improved through the application of cooperative script learning model in class VII SMPN 1 Soropia
\end{abstract}

Keywords: cooperative Script Learning Model, Listening Skills

\section{Introduction}

In the process of learning in school, many aspects that affect student learning outcomes, one of which is a model of learning applied by teachers in the learning process. The learning model used should be varied and tailored to the material taught in order to generate creativity and motivate students to learn effectively by working with other students in study groups. In addition, the learning model should be mastered by the teacher to facilitate in teaching to students. The learning model should involve students directly to be active in exercising their listening skills. A good learning model is a learning model that is appropriate to the material to be taught and a model that is able to involve students directly to be active in understanding the subject matter. By considering the above, teachers should be able to make an innovation in learning so that students feel interested and eager in receiving the material lessons given, so that students are expected to achieve learning achievements in accordance with KKM that has been established school. The listening aspect in language learning is often overlooked because the teacher is lazy to take the time to involve one by one student in order to practice their listening skills. It is not surprising that language learning has not developed the potential of listening to students, because there is no stimulation or channel provided by the teacher to develop the potency of listening to the students. Based on the observation that many children who have difficulty in learning Indonesian especially focused on the ability to listen. Most children do not listen well to what the teacher says so that what the teacher says can not be properly listened to. The explanation just goes away so that when the teacher gives an evaluation to the student, the student is unable to answer the questions from his teacher. This is also indicated from the value of daily reexamination of learning listening to students of class VII odd semester of Lesson 2043/2015 ago. The score of students who reach KKM is 60 only 6 people and those who do not reach KKM amount to 15 people with the percentage of classical completeness that is $28 \%$ with average value 55,38. Based on the results of observations and student scores in the Year Lesson 2014/2015 the author tries to find the solution of the term in the form of classroom action research that is applying a model of learning that can further enable students in training the ability to listen. Being skilled listening will support other language skills, such as speaking, reading and writing skills. Every single skill is closely related to other language skills in a variety of ways. In obtaining our conversational skill through the sequence of language skills, we learn to listen to the language, then talk afterwards we read, and write. Cooperative Script learning is an instructional model that classifies students in pairs. In a group there are only two students who are more active in learning, because they have their respective roles, namely as speakers and listeners. With this role, students will be more responsible for the role so that students will pay attention to the material to be studied. Therefore, the authors 
hope to use the cooperative Script learning model can improved listening skills in grade VII Semester 1 in SMPN 1 Soropia in the academic year 2016/2017.

\section{A. Language Learning with Listening}

\section{Literature Review}

In relation to language derivatives, there are four basic language skills according to Mulyati (2008), namely listening (listening) skills, speaking skills, reading skills and writing skills.From his research, Walter Loban (Solchan, 2008) concluded that there was an antenatal connection between students' language skills and language skills in learning.

a. Students with verbal speaking skills (listening and speaking) are effect less inclined if he wrote less effective and also proficiency (reading and writing).

b. There is a strong relationship between students' language skills with Academic ability gained.

In his book entitled Indonesian Language Skills SMP Mulyati (2008), defines listening as a comprehending skill Receptive spoken language. Thus, listen here not just listen to the sounds of language but understand it. There are two types of listening situations: the listening situation Interactive and no interactive listening situations. The following is Some micro skills are involved when we strive for Understand what we hear, the listener must: (a) Store / remember elements of the language heard using memory short-term; (B) attempt to distinguish the sounds of the language Distinguish meaning in language; (C) suppress the presence of forms of pressure And the tone, the color of sound, the intonation, and the existence of the reduction of the forms Words; (D) to distinguish and understand the meaning of the word being heard; (E) recognize Special word forms; (F) detecting those key words Identify topics and ideas; $(G)$ guess the meaning of context; (H)Know the word classes; (I) realizing the basic forms of syntax; (J) Recognize cohesive devices; And (k) detecting sentence elements Such as subject, predicate, object, preposition, and other elements. The purpose of listening in junior high in particular is: to train students to appreciate Others, training disciplinary students, training critical thinking students, training students Improve reasoning power, and train students to improve their abilities Speaking. Through the listening process students can master pronunciation Phonemes, vocabulary, meaning of words, and sentences. It is very helpful activity speaking students as active productive activities according to Tarigan (Solchan, 2008), because the vocabulary simultaneously a person will affect His speaking ability by Idra (Solchan, 2008).

\section{B. Model of Cooperative Script Learning}

Learning model means learning reference that is done based on these learning patterns systematically. The selection of the use of certain learning models is carried out according to certain learning steps and adapted to the students' ability, subject matter, student characteristics, and supporting learning process support (La Iru and Arihi, 2016). Of the two aspects above cooperative learning has the following characteristics: (a) positive interdependence that allows students to motivate each other to achieve optimal learning outcomes; (B) face-to-face interactions allowing students to become more focusing learning resources; (C) individual accountability for knowing individual student knowledge; And (d) the skills of interpersonal and social relationships. Learning Cooperative Script by Schank and Abelson (Hadi, 2007) is a study that describes the interaction of students as the student's social life illustration with the environment as an individual in the group family, community and the wider community. Brousseau (Hadi, 2007) states that the cooperative learning model indirectly scripts are learning contract between teachers and students and students and students know how to collaborate. ( Http://ejournal. umpwr. ac. id/index. php/radiasi/ article/view File/238/268 )

\section{According to Hamid (2016) cooperative learning steps of the script:}

a. teachers divide students to group;

b. The teacher distributes the materials of each student to read and create summary;

c. Teachers and students determine who first role as Speakers and whom the Master divides students into pairs;

d. The teacher distributes the listener as a listener;

e. The speaker read the summary as completely as possible Listeners listen to the basic ideas that are incomplete and helpful Recall the main ideas and relate them to other material;

f. Exchanging roles as speakers converted to listeners;

g. Student conclusion together with teacher; and

h. Cover.

The advantages of cooperative script learning model are as follows: (a) train hearing and accuracy; (B) each student gets a role; And (c) train others to reveal the faults of others (Miftahul A'la, 2016). The weaknesses of 
the cooperative Script learning model are as follows: (a) is only used for certain subjects; (B) only two do (not involving the whole class so that the correction is limited to the two persons only (Miftahul A'la, 2016).

\section{Previous Study}

Research relevant to the research writer is research Meaning Mustajab, et al. And Neneng Nengsih research, et al. The Meaning of Mustajab, et al. (2016) conducted a study entitled, "Application of Learning Method Cooperative Script to Improve Student Learning Participation Class VIIIA of SMP Negeri 2 Karanggayam in the academic year 2012/1013". The researchers concluded that cooperative learning methods the script can increase participation VIIIA grade students of SMP Negeri 2 Karanggayam the academic year 2012/2013. Learning participation increased from $57.02 \%$ in pre cycle to $64.91 \%$ in cycle one and $75.88 \%$ in cycle two. Increased student learning participation followed by improvement in student achievement. The average value of the past semester tests of 58 increased to $7 \mathrm{~L}$ at the end of the test the first cycle and 81 at the end of the test cycle 2. Response was very positive towards learning cooperative script. Students 'response to the previous study by 66,8 yo while learning cooperative students' response to the script by $69 \%$ and increase in cycle two being 75.4\%. Neneng Nengsih, et al. (2016) conducted a study entitled, "Application of Learning Model Cooperative Script to Improve Learning Outcomes Subjects of Natural Science Seventh Grade Students of SMPN Parungkuda 01 Sukabumi District School Year 2009-2016". Researchers Concluded that the average value of learning outcomes in the first cycle gain value $68,42(47 \%)$ while the second cycle get value 85,26 (87\%) and third cycle get value 91,89 (100\%), it mean happened improvement / improvement result of student learning Beside result of learning quality implementation of learning also increase In the first cycle obtained a value of $75.95 \%$, while the second cycle obtained a value of $85.18 \%$ and in the third cycle to get the value of $88.51 \%$, which means there is a quality improvement in the implementation of learning. Likewise with the results of student activity observations indicate the Increase in activity and student participation that get value in first cycle that is equal to $62,52 \%$, while the second cycle got the value of 80,10 and the third cycle of value acquisition increased to $82,52 \%$. This shows that the implementation of Cooperative script Learning model can improve learning outcomes subjects of Natural Sciences Student Class V Elementary School Parungkuda 01 Sukabumi. In addition, the implementation of this learning model can improve the quality of learning implementation and improvement of student behavior in the learning process.

\section{Hypothesis}

Based on the background of the problem and formulation of the problem that there is the hypothesis of this study is the application of action cooperative script learning model can improve listening skills class VII SMPN 1 Soropia.

\section{A. Types of research}

\section{Method}

The type of research used is Classroom Action Research (PTK). Aqib (2016) said that research on paper action is a research done by teachers in their own class with self reflection in order to improve their performance so that students' learning outcomes increase.

\section{B. Research Setting}

This classroom action research was conducted at VII of SMPN 1 Soropia. The study was conducted on Odd Semester Year 2016/2017 in Class VII because the low student learning outcomes especially Indonesian subjects focused on listening.

\section{Research subject}

Subjects in this study were students of class VII SMPN 1 Soropia Odd Semester Year 2016/2017 Lessons that amounted to 24 people, consisting of 11 men and 13 women.

\section{Factors to be studied}

\section{Factors studied in this research are:}

1. students is to see student activity and listening skills through cooperative learning model script; and

2. Teachers, which is seeing the teacher's activity in applying the cooperative Script learning model in class.

\section{E. Research procedure}

This research is a classroom action research (PTK) using cooperative learning model script. This study was conducted two cycles, with each cycle conducted twice as many meetings. Classroom action research (PTK) as an action plan for improving learning consists of: planning) implementation of action, observation, evaluation, and reflection. 
1. Cycle I

a. Planning

Planning made before conducting classroom action research is a continuation of the initial observation activities to obtain student value in listening activities. The steps taken are as follows:

1. a meeting with the principal of SMPN 1 Soropia And teachers Class to discuss preparation and time will be implemented research;

2. Preparing teaching materials to be used in learning According to the material to be studied;

3. Make the implementation plan of learning (RPP) by applying cooperative script learning models ;

4. Preparing teacher observation sheets and student observation sheets; and

5. Prepare worksheets and evaluation tools that evaluation questions per cycle.

\section{b. Classroom Action Implementation}

In the implementation stage, learning activities will be carried out according to the plan that has been made. The first cycle of learning activities are conducted twice attendance (RPP RPP 1 and 2) to implement cooperative script learning model.

\section{c. Observation and Evaluation}

Observation activities carried out on the implementation of the action by using the observation sheet that has been made. Teacher observation sheets are used to know the advantages and disadvantages of teachers in the learning process, while the student observation sheet is used to determine students' activeness in carrying out learning. The evaluation is done by using a written test, with the form of a description test. The evaluation was conducted to determine whether the student learning outcomes in subjects' listened Indonesian focus can be increased by applying cooperative learning model script.

\section{d. Reflection}

In the reflection activity the results obtained at the observation and evaluation stage are collected and then analyzed to get the learning picture that has been done. From the results of observation will be a reference to improve performance in teaching and evaluation results will be used as a reference for improvement in the next cycle.

\section{Cycle II}

\section{a. Planning}

Activities undertaken at this stage are:

1. Make improvements in cycle two, according to data obtained on Cycle one;

2. Preparing teaching materials to be used in learning Cycle II;

3. Make learning improvement plan (RPP) by applying cooperative learning model of an Script;

4. prepare observation sheets teacher / student; and

5. Prepare the evaluation tool that is LKS and the matter of evaluation per cycle.

\section{b. Implementation of Action}

In this activity the teachers implement instructional scenarios (RPP RPP 3 and 4) to improve the learning outcomes of students who have not completed the previous cycle by implementing cooperative script learning model.

\section{c. Observation and Evaluation}

In observation in this cycle II, observer that is classroom teacher observe the implementation of action by using observation sheet to observe teacher teaching activity and student learning activity in learning process, and evaluation of result learn to know success of teacher and student during learning process. If it has not reached the teacher and student performance indicator that has been determined then the research will be continued in cycle III and if it has reached the performance indicator that is determined then the research is stopped in cycle II.

\section{d. Reflection}

In the second cycle of reflection phase, the results of the observation and evaluation stage during the learning activities are collected and analyzed to determine the success of the learning process that has been done.

F. Data and Data Collection Techniques

1. Data source: the data obtained comes from teachers and students.

2. Types and data collection techniques: 
a. Quantitative data that is in the form of learning outcomes, taken through the test results learn.

b. Qualitative data that is in the form of activity of teacher and student, taken with Using observation sheets.

G. Data analysis technique

1. To calculate the value of the achievement level of student learning outcomes Individually with the formula:

$$
\mathbf{n}=\sum_{\text {Maksimum scores }} \text { Scores earned } \times 100 \%
$$

]

$\mathbf{n}=$ the value obtained by each student

: (Putra, 2016 )

2. Determine the average value of student learning outcomes $(\mathrm{X})$ by the formula:

$$
\begin{aligned}
& \mathrm{X}=\frac{\sum x \mathrm{~N}}{\mathbb{N}} \\
& \text { Information: } \\
& \mathrm{X}=\text { Average value } \\
& \Sigma \mathrm{Xi}=\text { Total score per student } \\
& \mathrm{N}=\text { Number of students }
\end{aligned}
$$

3. To calculate the percentage level of achievement of mastery learning outcomes of students with formula:

$\%$ Complete $=\frac{\Sigma f i}{n} 100 \%$

Information:

$\Sigma \mathrm{fi}=$ Number of students who complete the study

$\mathrm{N}=$ Total students overall

(Nasution, 2008)

4. Determine the percentage mastery of classical student activity with formula:

$\% \mathbf{K A B S}=$ Number of students earned $\times 100 \%$

Maksimum number of scores

\section{Criteria:}

$76 \%-100 \%=$ Good $26 \%-50 \%=$ Less

$51 \%-75 \%=$ Quite $0 \%-25 \%=$ Very Less

(Rohani, 2004)

5. Determine the percentage of achievement level of teacher activity and by Classical, by the formula:

$$
\% \text { KAMG }=\underset{\text { Maksimum number of scores }}{\text { Number of students earned }} \times 100 \%
$$

Criteria: (Soul, 2004)

$$
\begin{aligned}
& 76 \%-100 \%=\text { Good } 26 \%-50 \%=\text { Less } \\
& 51 \%-75 \%=\text { Quite } 0 \%-25 \%=\text { Very Less }
\end{aligned}
$$

\section{H. Performance Indicators}

Indicators of success in this study there are two kinds. The indicators are as follows:

1. activity of students and teachers said to be good bag if $\geq 80 \%$ aspects Learning improvement plan has been implemented; and

2. Student learning outcomes is successful or complete if $\geq 75 \%$ of students had reached a value of $\geq 60$, which is the default Criteria of Completeness Minimal (KKM SMPN 1 Soropia).

\section{Measures Cycle I}

\section{Result and Discussion}

Cycle I was held on 7 and 9 November 2016 and in two meetings with a 4 x 35 minute time allocation. The following is the implementation of the cycle I action.

\section{a. Planning}

Activities undertaken at the planning stage are as follows:

1. teachers prepare textbooks of Language subjects Indonesia class VII SMPN 1 Soropia used in the classroom according to the applicable curriculum In the school where the research is KTSP as learning materials; and

2. Make the implementation plan of learning (RPP) cycle I, sheet Student work (LKS), making observation sheet of teacher activity, making Student activity observation sheets, and make the cycle evaluation question I. 


\section{b. Implementation of Action \\ c. The first meeting}

The first meeting was held on November 7, 2016 in the first fourteen hours at 07.15-08.25. Before starting the lesson the teacher first checks the readiness of the students to follow the lesson after the students look ready, the teacher starts the lesson. In the early activities of learning things done by teachers are as follows: (1) checking the attendance of students; (2) condition the class in order that learning can be effective and conducive; (3) delivering learning objectives; (4) delivering learning steps; (5) to inform the material to be studied; And (6) distributes number 1-12. For those who get the same number will be a pair of his group. In the final activities of learning things done by the teachers are: (1) teachers with students to ask questions about the LKS just done; (2) after the teacher and students answer the LKS, the teacher directs the students to conclude the material just discussed; (3) the teacher closes the learning and gives a message to the students, in order to study hard and practice a lot of listening practice cooperative learning model script with a playmate.

\section{b. Second meeting}

The second meeting took place on 9 November 2016 the 14th week of the first hour at 07.1508.25. Before start the lesson of teachers first check the readiness of students to follow the lesson After students look ready, the teacher starts learning. In the early activities of learning things done by teachers are as follows: (1) checking the attendance of students; (2) condition the class in order that learning can be effective and conducive; (3) delivering learning objectives; (4) delivering learning steps; (5) to inform the material to be studied; And (6) divide the group according to a friend's seat. At the end of the learning activities of the steps undertaken by teachers are: (1) teachers with students to ask questions about the LKS just done; (2) after the teacher and students answer the LKS, the teacher directs the students to conclude the material just discussed; (3) the teacher closes the learning and gives the message to the students, so that they can study at home. The teacher also reminds students that in the last hour an evaluation will be held.

\section{c. Observation}

Observation activities are conducted to monitor firsthand the activities of teachers and students during the learning process in the classroom. Based on the observation of teacher activity in the learning process of cycle I, the percentage of teacher observation result reached $75.65 \%$ caused, there are some activities conducted by teacher but not maximally according to observer. Some activities that will be used as a stage of improvement of teacher teaching activities in cycle II are:

1. The teacher is very quick in explaining the learning steps cooperative script so that only some students who understand and listen;

2. Teachers are less motivating to the students to be enthusiastic follow learning process;

3. Giving less opportunity to students to ask questions; and

4. Supervision of teachers is still lacking, so there are some students who Noisy and not focused on their respective duties.

Based on the observation of student activities in the learning process Cycle I, the percentage of student observation reaches $69,64 \%$. Because, there are still four learning activities that have not been done well and will be material improvement in cycle II that is:

1. Students are still hesitant to ask the teacher;

2. Most students do not record learning objectives;

3. Most of the students have not been able to perform their role as Speaker and listener; and

4. Most students have not been able to deduce the material on learn.

\section{d. Evaluation}

At this stage, the first cycle evaluation is used to measure student learning outcomes. Evaluation in cycle I was done once on November 9, 2016. The evaluation test is done by the teacher reading the script twice. After gum read the story the teacher shared the questions along with the answer sheet to be answered by the students. The data obtained from this study were analyzed quantitatively and qualitatively based on the results of the actions undertaken in cycle I. Then the evaluation results from cycle I will be obtained from the value of students taken test cycle 1. Here is Table 4.1. Distribution of student learning outcomes cycle 1.

Table 4.1. Distribution of Student Learning Results Cycle I

\begin{tabular}{|c|c|c|}
\hline No & Gain & Results \\
\hline 1 & Completed & 11 \\
\hline 2 & Percentage Completion (\%) & 45.83 \\
\hline 3 & The highest score & 92.85 \\
\hline 4 & Lowest Value & 40 \\
\hline 5 & Class Average Value & 61.09 \\
\hline
\end{tabular}


From Table 4.1 can be seen the results of the learning cycle test I. This value is influenced by some teacher and student activities that have not been implemented so that student learning outcomes are also low. Some students are not too familiar with the model used. At the time of explaining the material some students are still noisy so that students are less familiar with the material described by the teacher. Based on Table 4.1, obtained the average value of students in the first cycle only reached 61.09. The highest value is 92.85 while the lowest value is 40 . Students who have reached KKM amounted to 11 people and who have not reached KKM amounted to 13 people.

\section{e. Reflection}

At this stage, what has not been done well in the learning process? The researcher along with the observer discusses the shortcomings in the implementation of cycle I that will be fixed in the next cycle. From the result of observation activity of teaching activity of teacher and student, and result of learning skill of listening show that performance indicator not yet reached. This caused teachers very fast in explaining the learning steps cooperative script so that only some students who understand and listen, the teacher is less motivating to the students to follow the spirit of the learning process, not providing to students to ask and supervision of teachers are still lacking, so there Some students are noisy and do not focus on their respective duties. Based on the shortcomings that existed in the implementation of the first cycle action, the observer and the researcher decided that this research should be continued in cycle II.

\section{Cycle II Action}

a. Planning

Activities undertaken during the planning stages are as follows:

1. teachers prepare textbooks of class VII SMPN 1 Soropia subjects Indonesian language used in the classroom as per the curriculum Apply at the school where the research is KTSP as material Learning; and

2. Make the implementation plan of learning (RPP) cycle I, sheet Student work (LKS), making observation sheet of teachers' activity, and Make observation sheet of student activity and make evaluation question Test cycle II.

\section{Implementation of Action}

Implementation of action cycle II was conducted with two meetings, namely on November 14 and November 16, 2016 in class VII SMPN 1 Soropia. At this stage the teacher and student activities in the learning process of learning as the first cycle, in accordance with cooperative learning steps script. The lesson material in cycle II is to determine the character of the character in the story at the first meeting and give advice on the character of the child story character at the second meeting.

\section{a. The first meeting}

The first meeting took place on 14 November 2016 the first 15 hours at 07.15-08.25. Before starting the lesson the teacher first checks the readiness of the students to follow the lesson after the students look ready, the teacher starts the lesson. In the early activities of learning things done by teachers are as follows: (1) checking the attendance of students; (2) condition the class in order that learning can be effective and conducive; (3) delivering learning objectives; (4) delivering the lesson steps; (5) to inform the material to be studied; And (6) divide students into groups. At the end of the learning activities of the steps undertaken by teachers are: (1) teachers with students to ask questions about the LKS just done; (2) after the teacher and students answer the LKS, the teacher directs the students to conclude the material just discussed; And (3) the teacher closes the learning and gives the message to the students, to be diligent to study at home. Noting that on Wednesday November 16th, there will be another test in the last lesson.

\section{b. Second meeting}

The second meeting took place on 16 November 2010 the 16th week of the first hour at 07: 1508.25. Before starting the lesson the teacher first checks the readiness of the students to follow the lesson after the students look ready, the teacher starts the lesson. In the early activities of learning things done by teachers are as follows: (1) check student attendance; (2) condition the class in order that learning can be effective and conducive;(3) delivering learning objectives; (4) delivering learning steps; (5) to inform the material to be studied; And (6) the teacher distributes 22 cards that have been prepared by the teacher. Of the 22 cards there are 11 pairs of cards of the same size and shape. Students will pair up with the matching pairs of cards they have. In the final activities of learning steps taken steps of teachers are: (1) teachers with students to ask questions about the LKS just done; (2) after the teacher and students answer the LKS, the teacher directs the students to conclude the material just discussed; And (3) the teacher closes the learning and gives the message to the students, to be diligent at home study. Convey that at the last lesson time will be conducted an evaluation test. 


\section{c. Observation}

The things observed in the implementation of the action cycle II by using cooperative script learning model is teachers' way to carry out learning activities whether it is in accordance with the learning scenario that has been created or not. In addition, also seen student learning activities in following the lesson and observing activities that did not happen in the first cycle, either from the activity of teaching teachers or student learning activities. Based on teacher activity observation in learning process of cycle II, teacher activity has increased compared to cycle I and deficiency that exist in cycle I has been improved and implemented in cycle II. These results when precentage reach $86.84 \%$. Furthermore, the observation of student activities in the learning process of cycle II also increased compared to the previous cycle. The increase was shown from the percentages obtained to reach $86.54 \%$, the student activity run in accordance with the learning scenario.

\section{d. Evaluation}

At the evaluation stage together with the evaluation of the second cycle in cycle I. At this stage of the second cycle evaluation to determine student learning outcomes. Evaluation of cycle one done as much as one that is on November 16, 2016. The evaluation test carried out by the teacher read the script the story twice. After the teacher read a story to share about the teachers and their answer sheets to be answered by the students. Data obtained from this study were analyzed quantitatively and qualitatively based on the results of actions taken on the second cycle. Then the results of the evaluation of the second cycle will be obtained from the value of students drawn test cycle II. Data from listening skill assessment seventh grade students of SMPN 1 Soropia through cooperative script learning model in the second cycle, can be seen in Table 4.2 below.

Table 4.2. Distribution of Student Results Cycle II

\begin{tabular}{|c|l|c|}
\hline No & \multicolumn{1}{|c|}{ Results Achievements } & Results \\
\hline 1 & Complete & 21 \\
\hline 2 & Completeness percentage (\%) & 87.50 \\
\hline 3 & The highest score & 100 \\
\hline 4 & lowest Rated & 50 \\
\hline 5 & Average Value Class & 81.00 \\
\hline
\end{tabular}

From Table 4.2, individual scores two cycle tests have been increased. The highest value students have reached 100 and the lowest is 50. The increase was due to an increase in the activity of teachers and teaching activities teach students that support the improvement of student learning outcomes in the second cycle. Increased student learning activities so that students can understand the material presented well. Based on Table 4.2. average values obtained in the second cycle students reached 81 . The increase in the average value of the classical in cycle two affected the learning process at the meeting of 1 and 2 meetings in the second cycle. The learning process in the classroom has been operating effectively. Students have practiced well cooperative learning model script. Students already carry out their role as speaker and listener so that when the cycle test of two students had been more focus on listening to the story and most students are able to answer correctly. Therefore, in this second cycle average value classically students already meet the standards defined performance indicators.

\section{e. Reflection}

Based on the activities carried out in the second cycle showed good results. Results of teacher activity observation and observation of student activity showed that by using model cooperative script, teaching activities of teachers and students' learning activity can be improved. Student learning outcomes also increased, although there are still some students who have not achieved mastery learning. If seen from the results of tests on the evaluation of the implementation of the second cycle, students who achieve mastery learning has reached $87.50 \%$, this research has been successfully carried out according to plan the implementation of the research with two cycles.

\section{Discussion}

Classroom action research was conducted in two cycles, with each cycle consisting of two meetings held in accordance with the procedures of research using learning model cooperative script. In the implementation of learning in each class the first cycle and the second cycle adapted to the steps models of Cooperative script learning. Based on the evaluation of learning, the study ended after the implementation of the second cycle for the observation of the teacher, and the observation of student activity has reached a predetermined performance indicators that is at least $80 \%$ complete. Student learning outcomes has also reached the performance indicators determined that $75 \%$ of students had reached $\geq 60$ according KKM KKM spoken at SMPN 1 Soropia. This study was done to improve listening skills of students in learning. Tarin (1990), stating that listening is a listening process verbal symbols with caring, understanding, appreciation and interpretation of 
information capture the content or the message and understand the meaning of communication that have been submitted by the speaker of the spoken language or speech. Within the meaning of the above in this study to train students listened ability to engage directly into the speaker and listener. Speakers will deliver the message (gathering material) then the listener will get the message that he heard and until eventually they will exchange roles so that, all students have the same opportunity to practice listening. Learning is a process that contains a series of works of teachers and students on the basis of reciprocal relationships that take place in an educational atmosphere to achieve certain goals, Hamid (2016). The learning process is also the interaction of all components or elements contained in the study, which are interconnected with one another in a series to achieve the goal. As for which is included in the learning components such as the objectives, materials, tools, methods, models, and assessment. Therefore, to make it easier to listen to the students in this study teacher's use learning scenarios that incorporate the use of materials, models, and methods appropriate to the objectives to be achieved. Teachers used cooperative Script learning models and methods of lecture and discussion in order to create a reciprocal process between teachers and students. So with the use of the model and the method is not only active teacher explain but students will also be active in this study. Of activities teaching activities that teachers in the first cycle and the second cycle there are some advantages and disadvantages of using cooperative learning model script. Excess learning model cooperative script as follows, Miftahul A'la (2016) is coaching hearing, precision / accuracy, each student got the role, and the train revealed the mistakes of others by word of mouth. The weakness of the learning model cooperative script consits only used for certain subjects and conducted only two people (not involving the whole class so that the correction was limited to two people).However, in this study a model cooperative script learningI have done by involving all students to pair up with the teacher's supervision. So every student can plays a role in his seat each and the teacher would go around oversee each pair so that they can make learning model measures cooperative script and learning results obtained in accordance hear applied learning models. The learning objectives should be centered on the desired changes in student behavior, and therefore should be operationally defined, measurable, and can be observed accievement. According Sudjana (Iskandar, 2016), learning outcomes are a result dar 'learning by using a measurement tool, namely in the form of a planned test well organized written tests, oral tests and the test works. Nasution (Iskandar, 2016), states that the results of learning is a change in individuals who learn not only the knowledge, but also develop skills and appreciation in the person of individuals studied. Thus, the learning outcomes are results obtained by students after attending a specific material of specific subjects such as quantitative and qualitative data. Teacher according to research conducted using an evaluation tool in the form of a written test which shows the results of student learning to train the ability to listen for them in the first cycle and the second cycle. Teachers also prepare observation sheets teachers and students to measure the results of teachers' activity cycle I and cycle II and, the results of student learning activities first cycle and the second cycle. From the results obtained teaching activities of teachers and students learning activities has reached a predetermined performance indicators. The results of the observation of the learning implementation can be said to be good, the whole component in learning scenarios have been carried out properly in accordance with the objectives to be achieved. Because the learning outcomes of students shows most students completed, then the hypothesis actions have been reached with the following results: all the components in the learning scenarios have been carried out properly in accordance with the objectives to be achieved. Because the learning outcomes of students' shows most students completed, then the hypothesis actions have been reached with the following results are all the components in the learning scenarios have been carried out properly in accordance with the objectives to be achieved. Because the learning outcomes of students shows most students completed, then the hypothesis actions have been reached with the following results:

1. Application of learning models of cooperative script can improve student listening skills class VII SMPN 1 Soropia ;

2. Cooperative script learning model application can enhance the activity of teaching in learning Indonesian teachers in class VII SMPN 1 Soropia; and

3. Application of learning models of cooperative script can increase the activity of students of class VII SMPN 1 Soropia.

\section{Conclusion}

Based on the results of research and discussion, it was concluded by using model study of Cooperative script can improve students' listening skills. This can be seen in the discussion of student learning completeness percentage obtained in the first cycle with an average value of 61.09 with the percentage of completeness in classical $45.83 \%$ and increased in the second cycle by average to 81 with the percentage of completeness in the classical $81,50 \%$. Improved listening skills with the use of learning model cooperative script is supported also by the increased activity that is $75.65 \%$ of teachers teaching in the first cycle and then increased by $86.84 \%$ in the second cycle and the increased activity of students in the first cycle that $69.64 \%$ and increased in cycle II reached $86.54 \%$. 


\section{Suggestion}

1. For teachers was to applying the learning model cooperative script in the learning process because it can enhance the teaching activities of teachers, particularly on the subjects of Indonesian.

2. For students to practice learning model cooperative the script with his friend to practice listening. The need for further research into the learning process by using learning model cooperative script not only in the eyes of Indonesian subjects but all other subject areas.

\section{References}

[1] A'la, Miftahul. 2016. Quantum Teaching. Yogyakarta: Diva press.

[2] Arikunto, Suharsimi. dkk. 2016. Penelitian Tindakan Kelas. Jakarta: PT Bumi Aksara

[3] Aqib, Zainal.2016. Model-Model, Media dan Strategi Pembelajaran Kontekstual (Inovativ). Bandung: CV Yrama Widya.

[4] Aqib, Zairral- 2016. Penelitian Tindakan Kelas. Bandung: CV Yrama Widya.

[5] Bestari, Prayoga dan Ati Sumiati. 2008. Menjadi worga Negara yang Baik Jakarta: Pusat Perbukuan Departemen Pendidikan Nasional.

[6] Carlina, Astryd. 2016. Akibat Kurang Menjaga Kebersihan. http:llastrydcarlina. blogspot. Com 2016 /02/ cerpen-akibat-kurang menjaga-kebersihan.html (diakses 25 September 2016).

[7] Guntur, Henry Tarigan. 1990. Menyimak Sebagai Suatu Keterampilan Berbahasa. Bandung: ANGKASA.

[8] Iskandar. 2AlA. Penelitian Tindakon Kelas. Jakarta Selatan: REFERENSI (GP Press Group).

[9] La Iru dan La Ode Safiun Arihi. 2016. Pendekatan, Metode, Strategi, dan Model- Model Pembelajaran. Bantul: Multi Presindo

[10] Mulyati, Yeti dkk. 2008. Keterampilan Berbahasa Indonesia SMP. Jakarta: Universitas Terbuka.

[11] Mustajab, Maksud, Sriyono dan Siska Desy Fatmaryanti. 2016. Penerapan Metode Pembelajaran Cooperative Script untuk Meningkatkan Partisipasi Belajar Siswa Kelas VIII A SMP Negeri 2 Karanggayam Tahun Pelajaran 2016 /2014 dalam jurnal Radiasi. Vol. 1. No. 1

[12] (http://download.portalgaruda.org/article.php?article:9396 \&val=614), diakses 25Mei2016 .

[13] Nasution, Noehi dan Adi Suryanto. 2008. Evaluosi Pengajaran. Jakarta: Universitas Terbuka.

[14] Nengsih, Neneng, Dadang Kurnia dan Saur Tampubolon. 2016 . "Penerapan Model Pembelajaran Cooperative Script untuk Meningkatkan Hasil Belajar Mata Pelajaran Ilmu Pengetahuan Alam siswa kelas V SMP N Parungkuda 01 Kabupaten Sukabumi tahun $\quad$ pelajaran $2016 \quad / 201$ dalam (http://ejournal.unpak.ac.id/download.php?file:mahasiswa\&id=521\&name=7.\%20Jurnal\%20neneng\%20nengsih.pdf), diakses 25 September 2016.

[15] Nur'aini, Umri dan Indriyani. 2008. Bahasa Indonesia untuk Kelas III. Jakarta: Pusat Perbukuan Departemen Pendidikan Nasional.

[16] Puspitaheni. 2C1A. Menjaga Kebersihan Lingkungan. http://anotherscribblenote. wordpress. Com/2010/01/19/menjaga-kebersihanlingkungat/ ( diakses 25 September 2016 )

[17] Putra, Setiatava Rizema. 2016. Desain Evaluasi Belajar Berbasis Kineria. Joglakarta: DIVA Press.

[18] Rohani, Ahmad. 2004. Metode Pengelolaan Pengajaran. Jakarta: Rineka Cipta.

[19] Rositawaty, S dan Aris Muharam. 2008. Senang Belajar llmu Pengetahuan Alam. Jakarta: Pusat Perbukuan Departemen Pendidikan Nasional.

[20] Satori, Djam'an dkk. 2016. Profesi Keguruan. Jakarta: Universitas Terbuka Departemen Pendidikan Nasional.

[21] Sholeh, Moh. Hamid. 2016. Metode Edutainment. Jogsakarta: DIVA Pers

[22] Slameto. T995. Belajar dan Fahar-fahor yang Mempengaruhinya. Jakarta: PT. Rineka Cipta.

[23] Solchan T. W dkk. 2008. Pendidikan Bahasa Indonesia di SMP .Jakarta: Universitas Terbuka Departemen Pendidikan Nasional.

[24] Wardhani, IGAK dan Kuswaya Wihardit. 2016. Penelitian Tindakan Kelas. Jakarta: Universitas Terbuka Departemen Pendidikan Nasional. 